\title{
Methodology of assignment of Mineral Deposits of Public Importance proposed by MINATURA2020 Project and results of its pilot testing in the Dolnośląskie Province (SW Poland)
}

\section{Introduction}

Exploitation of mineral deposits in Europe is an activity necessary to meet present and future needs of the European society for raw materials. This is why it is necessary to ensure sufficient opportunities for exploration and exploitation of these deposits being primary sources of mineral raw materials (Galos and Smakowski 2008). Simultaneously, raw materials needs of our society must be met without prejudice to the possibility of meeting such needs by future generations. Therefore, mineral deposits available for exploitation have to be assessed in relation to other competing land uses, taking into account various aspects related to agriculture, forestry, protection of fauna and flora species, other environmental circumstances, settlement priorities, as well as existing and planned infrastructure.

However, access to mineral deposits must also be consistent with the public interest related to minerals' security, involving also the possibility of satisfying the needs for minerals by imports (EC Enterprise and Industry 2013). Choice between these diverse directions of land use requires adequate consideration of such aspects as the exclusive direction of some

* Ph.D. Eng., ** D.Sc. Eng., Associate Professor of MEERI PAS, *** M.Sc. Eng., The Mineral and Energy Economy Research Institute, Polish Academy of Sciences, Krakow, Poland;

e-mail: a.kot-niewiadomska@min-pan.krakow.pl 
land use, the reversibility of this process and the consequences for the environment. Choice between mining or other land use should be settled on the basis of detailed analysis, with use of e.g. multiple criterion methodology of mineral deposits evaluation (Nieć ed. 2013).

In response to this challenge MINATURA2020 project, financed within Horizon 2020 program, was launched in February 2015. Its main objective is to prepare concept and methodology for the definition and subsequent safeguarding of Mineral Deposits of Public Importance (MDoPI) to assure their optimal use in the future. It could be provided e.g. by some set of recommendations of MDoPI assignment. The main driving force of MINATURA2020 project is to ensure proper spatial planning policy, guided by the principle of sustainable development in relation to the exploitation of mineral deposits (Minatura 2020, 2015).

General initial approach and methodology (set of qualifying conditions) for MDoPI assignment was proposed in December 2016 (Galos et al. 2016). Then, it was tested in selected partner countries (Hungary, Italy, Poland, Portugal, Slovenia, Sweden, Ireland-UK offshore), taking into account different national policy scenarios and their impacts to ensure its viability at all levels (local/regional, national and EU). The tested cases differ from each other regarding: territorial size, mineral wealth, location (mostly onshore, with one offshore case) and Mineral Policy in force. One of the tested areas has been Dolnośląskie Province in Poland, with selected groups of minerals, deposits of which have been tested: magmatic and metamorphic crushed and dimension stone, feldspar raw materials, kaolin, glass sand.

\section{Aims and scope of MINATURA2020 Project}

MINATURA2020 is a three-year EU project that relies on the strength of an international consortium of 24 partners. All project partners have a demonstrated record of accomplishment of projects at national, international and commercial level. They are active players in the international raw materials community, part of a well-established network and cover different domains (public authorities, industry, academics, civil society, etc.).

The overall objective of MINATURA2020 is to develop a concept and methodology for the definition and subsequent protection of Mineral Deposits of Public Importance in order to ensure their "best use" in the future so that they may be included in a harmonised European guidance. Providing a policy-planning framework that comprises the sustainability principle for mining like for other land uses is the key driving force behind MINATURA 2020. One of expected results is also proposal of implementation of MDoPI concept into mineral policies and spatial planning policies at various levels: EU level, EU Member State level, regional level (Galos 2013; EC Enterprise and Industry 2010).

Mineral policy at country level is commonly defined as all actions of the state which can influence development of both supply and demand for mineral raw materials in this country. Indicated element of this policy is a mineral supply planning policy, which should be integrally linked to spatial planning policy (Galos 2013). Within the framework of country's mineral policy, first the leading document (Mineral Statement) should be submitted, which 
shows the importance of mineral raw materials for society and for the national economy, as well as the importance of ensuring adequate access to the national mineral resources, taking into account projection of medium- and long term domestic demand for mineral raw materials (Tiess 2011; Galos et al. 2012). Mineral supply planning policy should be a tool for ensuring access to domestic mineral sources (mineral deposits, secondary sources), being strictly correlated with spatial planning policy of adequate level. It should be first implemented at the strategic (domestic) level, and then at the following operational levels: provincial/regional, municipal/local (Nieć et al. 2014).

Spatial planning is by its nature an integrated process, dealing with various possible land uses (waters, forests, agricultural areas, protected environment, mineral deposits, etc.), with distinction of areas for different purposes. This process is - depending on a country - realised at regional or local level, but it should be linked to planning at strategic (domestic) level. Therefore, spatial (zoning) plans at various levels should be the key tool assuring access e.g. to mineral deposits, especially to the most valuable of them. For such purposes, the relevant criteria of qualification of strategic areas of mineral deposits should be proposed and implemented (EC Enterprise and Industry 2010; EC Enterprise and Industry 2014). Ideally, the various levels of land use planning (domestic, regional, local) in relevant planning documents should allow for safeguarding of mineral deposits (especially the most valuable of them for future extraction), in reference to the anticipated demand for mineral raw materials at the national, regional and local level (Wrighton et al. 2014; Nieć et al. 2014).

In such approach, authorities responsible for land use planning at various levels among their tasks would have identification of areas: where mineral deposits extraction should be a priority, where mineral deposits extraction is possible under certain conditions, and where mineral deposits extraction is not possible (Galos and Nieć 2015).

MINATURA2020 project consists of 7 Work Packages (WP), including 5 thematic ones (WP1-WP5, Fig. 1). The key Work Package for the whole project seems to be WP2, aimed at developing a harmonised definition of MDoPI, and a proposal of MDoPI assignment methodology. For these purposes, it was necessary to review currently used definitions and concepts related to this topic, which are used in various ways in particular countries of EU. Appropriate definition and qualifying criteria for the concept of Mineral Deposits of Public Importance has to be so inclusive to allow for uniform application of such concepts both at EU level and particular EU Member State level, taking into account the diversity of their legal systems related to management of mineral deposits. Another important aspect is the necessity to take into account the diversity of positions of various stakeholders regarding possible mining direction of land use (Galos and Nieć 2015).

WP3, WP4 and WP5 scopes are strictly related to the results of WP2. The aim of WP3 is to work out common proposal of optimal way of MDoPI concept implementation (by some kind of recommendations), taking into account the diversity of legal systems of each EU country. The aim of WP4 is to carry out pilot demonstration works with testing of MDoPI assignment methodology in a few EU regions (e.g. the whole area of Slovenia, selected region of Poland, Hungary, Italy, Portugal, Sweden, offshore area between the UK and Ireland). 


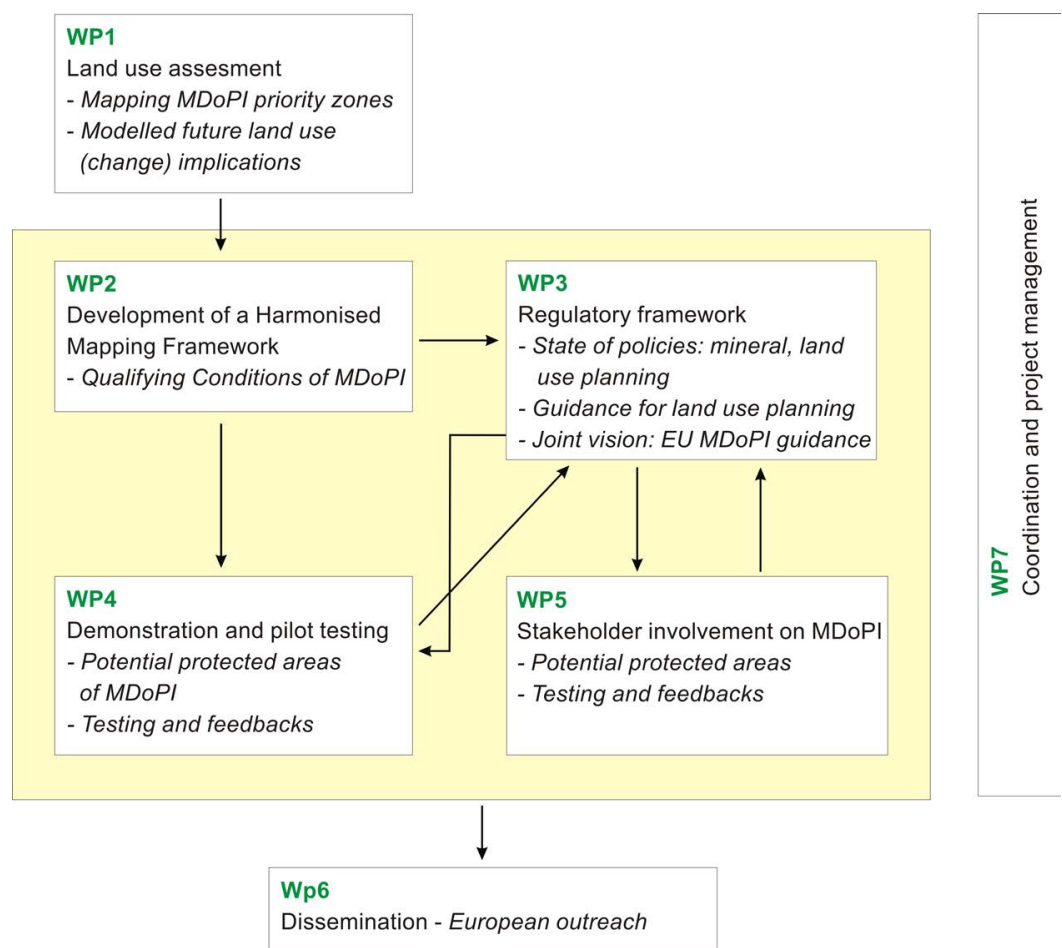

Fig. 1. The general structure of MINATURA2020 Project and relationships between Work Packages

Rys. 1. Ogólna struktura projektu MINATURA2020 oraz związków między Pakietami Roboczymi

Within WP5 the proposed MDoPI concept is consulted with stakeholders in particular EU countries through three rounds of consultations. Such consultations are expected to be carried on also at EU level, with final establishment of Stakeholder Council (Galos and Nieć 2015).

\section{General description of the subject of testing}

Dolnośląskie Province is located in SW part of Poland. It covers an area of $19,947 \mathrm{~km}^{2}$, i.e. $6.4 \%$ of the country's territory (Central Statistical Office 2016). It is a distinctive region in terms of wealth and diversity of resources of the natural and cultural environment. There are recognised more than 1,000 deposits of various minerals, including the largest in the worldwide scale and the only in Poland deposits of copper and silver ores, as well as important deposits of energy minerals (lignite) and numerous rocks minerals, e.g. crushed and dimension stones, sand and gravel aggregates, clay minerals, the highest quality glass sand, unique deposits of kaolin and feldspar raw materials and reservoirs of thermal and healing waters (Fig. 2). It is worth mentioning that crushed and dimension stones deposits in Dolnośląskie Province represent a 96\% of the total country's resources of magmatic and 


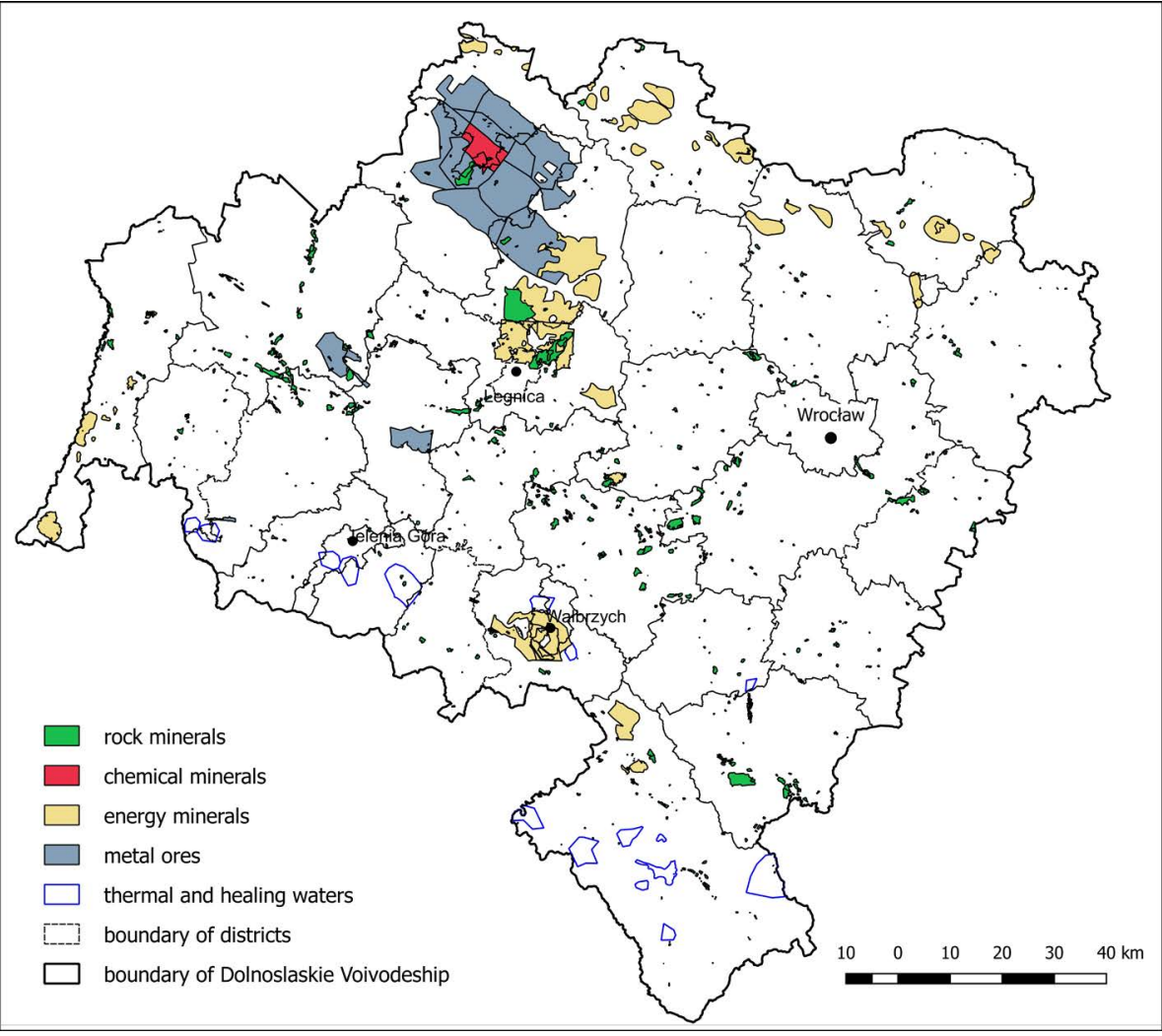

Fig. 2. Location of mineral raw materials deposits in the Dolnośląskie Province (based on data from the Central Geological Database, as of 31.12.2015)

Rys. 2. Lokalizacja złóż kopalin w województwie dolnośląskim (na podstawie danych z Centralnej Bazy Danych Geologicznych, stan na 31.12.2015 r.)

metamorphic rock minerals, while the mining production of these rocks in 2015 accounted for around $42 \%$ of the total dimension and crushed stones production (Kot-Niewiadomska and Kamyk 2017). Moreover, the total domestic production of bentonite, kaolin, feldspar raw materials and refractory clays comes from Dolnośląskie Province (Table 1). Simultaneously, according to the Central Statistical Office (2016) around $0.3 \%$ of the Province territory, i.e. 6,177 ha, was occupied by open-pits in operation, which was the largest percentage in Poland.

The region is also characterised by outstanding nature and landscape values (Fig. 3). There are all forms of the nature legal protection present: 2 national parks, 12 landscape parks, 57 natural reserves, 18 protected landscape areas, 11 areas of the Natura 2000 network and numerous areas covered by international agreements. As a result, almost $20 \%$ of the Province territory is covered by various forms of nature protection. Furthermore, there are favorable soils and climate conditions to carry out diverse agricultural production (more 


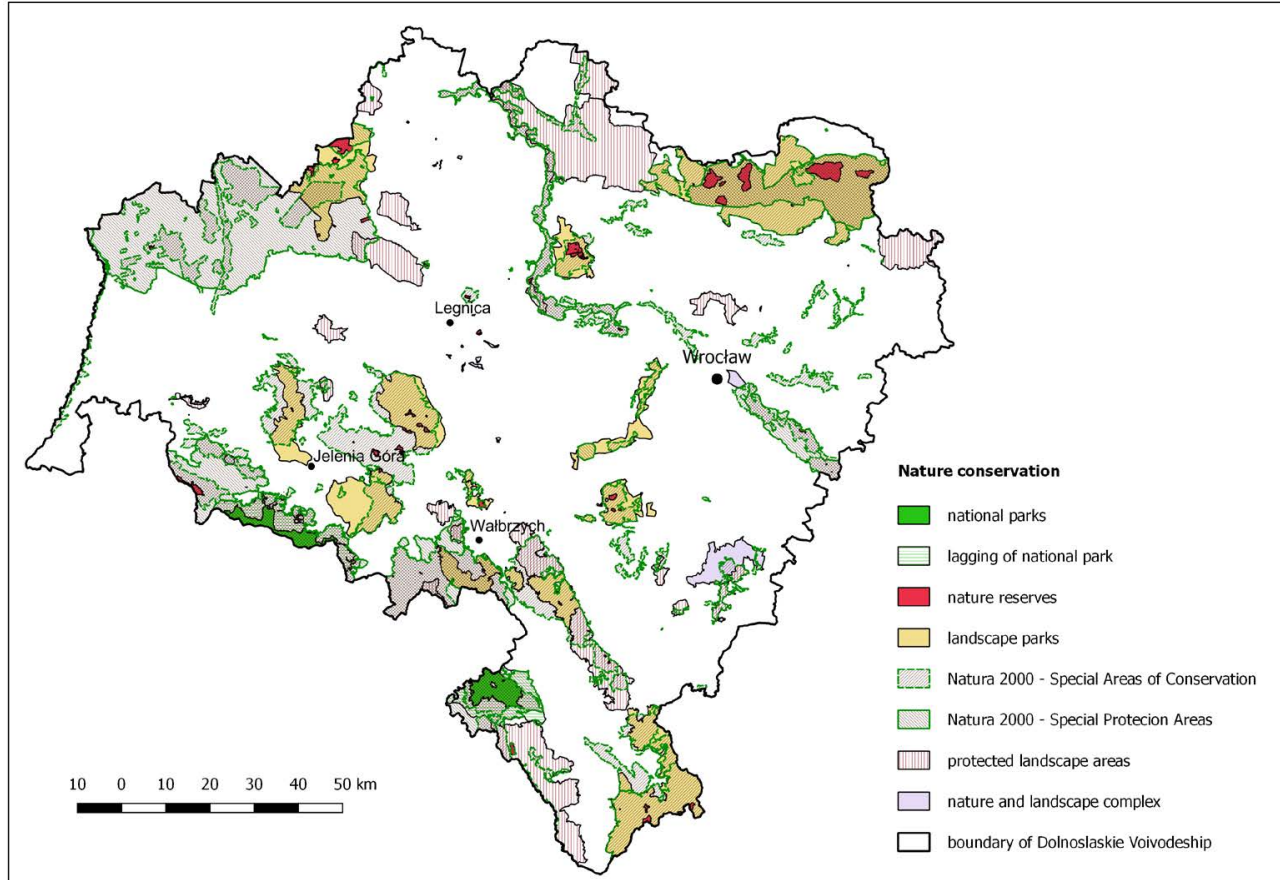

Fig. 3. Areas of protected environment in Dolnośląskie Province (based on General Directorate for Environmental Protection data, as of 31.12.2016)

Rys. 3. Obszary ochrony środowiskowej w województwie dolnośląskim (na podstawie danych Generalnej Dyrekcji Ochrony Srodowiska, stan na 31.12.2016 r.)

Table 1. Mineral resources of selected minerals of Dolnośląskie Province on the background of country (as of 31.12.2015)

Tabela 1. Zasoby bilansowe wybranych grup kopalin w województwie dolnośląskim na tle kraju (stan na 31.12.2015)

\begin{tabular}{|l|c|c|c|c|c|c|}
\hline \multirow{2}{*}{\multicolumn{1}{|c|}{ Minerals }} & \multicolumn{2}{c|}{ Poland } & \multicolumn{2}{c|}{ Dolnośląskie Province } & \multicolumn{2}{c|}{ Province's share [\%] } \\
\cline { 2 - 7 } & $\begin{array}{c}\text { resources } \\
{[\mathrm{kt}]}\end{array}$ & $\begin{array}{c}\text { production } \\
{[\mathrm{kt}]}\end{array}$ & $\begin{array}{c}\text { resources } \\
{[\mathrm{kt}]}\end{array}$ & $\begin{array}{c}\text { production } \\
{[\mathrm{kt}]}\end{array}$ & resources & production \\
\hline $\begin{array}{l}\text { Magmatic and metamorphic } \\
\text { crushed and dimension stone }\end{array}$ & 5771975 & 29656 & 5480199 & 26817 & 95 & 90 \\
\hline Glass sand & 625474 & 2669 & 85832 & 655 & 14 & 25 \\
\hline Feldspar raw materials & 137309 & 76 & 136944 & 76 & 100 & 100 \\
\hline Kaolin & 212077 & 287 & 212077 & 287 & 100 & 100 \\
\hline
\end{tabular}

Source: own study, based on Mineral Resources Datafile 2016. 
than $50 \%$ of the area account for cultivated land with high quality soil). Simultaneously, around $30 \%$ of the area is wooded including $74 \%$ of protective forests.

The most important strategic documents of the Province are: Development Strategy of the Dolnośląskie Province 2020 (2013) and Spatial Development Plan of the Dolnośląskie Province - 2020 Perspective (2014). The Development Strategy (2013) includes, among others, the following priority activities:

- protection of energy resources of Dolnośląskie Province (especially lignite deposits);

- development of transportation system of rock aggregates by rail without burdening the road infrastructure in the region;

- preventing conflicts arising from exploitation of raw materials.

According to Spatial Development Plan (2014) some of the main obstacles of the Province' development are:

- deterioration of nature and landscape features due to economic activity and urbanisation;

- pressure for undertaking mining of deposits (especially of rocks) in potential conflict areas (social, environmental);

- relatively large territories occupied by mines (as compared to the whole country) as well as increasing areas of degraded terrain relief caused by extraction of mineral raw materials.

According to the above mentioned documents the future development of the Province will be based on two pillars: (1) development of the modern industry, with optimal utilisation of the resource base, and (2) protection and provision of natural resources (including mineral deposits), as well as landscape and cultural values.

Despite postulated protection (only of fuels) as well as sustainable and reasonable economic use of natural resources, there is a lack of instruments for fulfilling of the goals proposed. It is suggested, in turn, to minimise/avoid potential social and environmental conflicts referring to mining activity even by abandonment of extraction in areas covered by various forms of protection. This results from location of many deposits (both exploited and unexploited) within such areas, which generates social opposition. On the other hand Spatial Development Plan (2014) includes notation that mineral deposits shall be taken into account in provincial spatial development plans. However, this does not mean automatically their protection for future generations. Moreover, there is no list of deposits of potentially strategic status that should be included in local and regional spatial development plans. Certainly, this list should include deposits of unique raw materials in the country, i.e. kaolin, feldspar or clays, especially white-firing, stoneware and refractory, as well as crushed and dimension stones and gravels that occur in the Dolnośląskie Province. According to Spatial Development Plan (2014), the system of preserved areas is to be expanded and consolidated, with a view to integration with other domestic and European systems. This probably will also generate potential conflicts, as there is an overriding weight of nature and landscape conservation in establishing terms and conditions of land use. This protected zone will cover almost all the Sudetes and Sudetes Foreland, where all the documented deposits of dimension 
and crushed stones are located (Kot-Niewiadomska and Kamyk 2017). The same problem refers to the central part of the Province covered with high quality of soils, the agricultural use of which have been guaranteed by Spatial Development Plan (2014).

Among the numerous deposits in Dolnośląskie Province, for testing of proposed MDoPI assignment methodology only four groups have been selected (in accordance with analysis which was carried out in WP1 - Land use assessment). Selected groups (magmatic and metamorphic crushed and dimension stones, kaolin, feldspar raw materials, and sand for glass production) represent deposits unique in Poland (Table 1) and important for economic development of the country and the region.

Selection of deposits from appropriate mineral groups was based on results of valorisation of unexploited rock mineral deposits carried out in 2011-2013 (Nieć ed. 2013). Selected deposits were qualified for high and medium protection. The list was updated as of 31.12.2015. Finally, the proposed methodology of MDoPI designation has been tested for 73 mineral deposits with indicated and/or measured resources, including: 50 deposits of magmatic and metamorphic crushed and dimension stone, 6 deposits of feldspar raw materials, 10 deposits of kaolin and 7 deposits of glass sand.

\section{General assumptions of MDoPI assignment in MINATURA2020 Project}

The starting point for development of methodology of MDoPI assignment was definition of MDoPI. Very wide and inclusive definition of Mineral Deposits of Public Importance was finally accepted by MINATURA2020 project partners in November 2016: "A mineral deposit is of public importance where information demonstrates that it could provide sustainable economic, social or other benefits to the EU (or the member states or a specific region/municipality)."

Following the definition, there was further discussion on joint assumptions and a common approach methodology of assignment of Mineral Deposits of Public Importance, including:

- scope of further analyses: what kind of minerals, what types of mineral objects - perspective areas, mineral deposits, etc.;

- multiple dimensional approach to MDoPI assignment: MDoPI at EU level, at country level, at regional (and/or local) level;

- taking as a basis - for the common MDoPI assignment methodology and the qualifying conditions - the existing good practices within EU countries;

- use of a common terminology regarding e.g. classifications, types of minerals, influencing factors, ranking/scoring, etc.

Finally, it was proposed to group MDoPI qualifying conditions in four various dimensions: geological knowledge, technical and economic, competing land use, and societal one. The whole proposed system of qualifying conditions and MDoPI assignment methodology 
was agreed for all EU countries/jurisdictions as a kind of the Project Recommendations. The general framework was only proposed, while details of qualifying conditions can be established separately by each country/jurisdiction (Galos et al. 2016).

The subject of MINATURA2020 project are only non-energy minerals, which - according to usual practice - can be divided into three main sub-groups according to the different physical and chemical characteristics of the minerals produced, their uses, and the downstream industries they supply: metalliferous minerals (metals ores), industrial and construction minerals.

For the purposes of MINATURA2020 project, it was decided that any kind of results from exploration which indicate areas of minerals with potential to become a deposit, should also be considered as a potential MDoPI. These are preliminary prospecting/ exploration areas (mineral potential areas) with estimated prospective (hypothetical) resources. It was a subject of discussion between Project partners whether mineral deposits currently operated should also be included in the MINATURA2020 project definition of MDoPI or not. As in numerous cases mining licenses can be revoked or not to be prolonged due to some social, environmental or regulatory constraints, it was decided that all known deposits can be included in MDoPI assessment. So, also in such cases the project would also test and validate the MDoPI criteria because specific areas/tracts hosting mineral deposits with known reserves and a mining license could be well positioned in any kind of MDoPI ranking. Taking the above into account, a broad approach to the term of potential MDoPI to be safeguarded was adopted, which can include:

- mineral potential areas having only undiscovered resources (speculative resources);

- hypothetical resources (according to USGS definitions) or promising exploration results;

- mineral deposits having estimated mineral resources (measured, indicated, inferred);

- mineral deposits with mineral reserves (probable, proved) and mining licence.

However, each EU Member State would decide whether to include - in the future MDoPI assignment - mineral deposits currently operated, or to focus on undeveloped areas exclusively.

One of MINATURA2020 project's aims is that Mineral Deposits of Public Importance (MDoPs) will be recognised/defined at three levels: EU level (MDoPI-EU), country level (MDoPI-CL) and regional level (MDoPI-RL). Threshold values between MDoPI-EU and MDoPI-CL, and between MDoPI-CL and MDoPI-RL for deposits or potential areas of metalliferous minerals and industrial minerals, as well as between MDoPI-CL and MDoPI-RL for deposits or potential areas of construction minerals, would be decided autonomously by each EU country. It should depend - among others - on country's mineral wealth, and domestic and regional consumption patterns. Periodical revision of MDoPI classification should be performed due to e.g. advances in geoscientific knowledge, development of innovative mining and processing methods, changes of consumption patterns for various minerals and changes in mineral's demand at domestic and regional level. It needs to be emphasised, however, that mineral deposits recognised as MDoPI-EU would automatically 
be recognised also as MDoPI-CL and MDoPI-RL, while MDoPI-CL - also as MDoPI-RL (Galos et al. 2016).

\section{Proposed qualifying conditions for MDoPI designation}

Criteria (qualifying conditions) for designation of MDoPIs are based on existing good practices, e.g.: Austrian Mineral Resources Plan (Der Österreichische... 2012); Mineral Deposits of National Interest of Sweden (Riksintresse... 2016); Valorisation of undeveloped mineral deposits in Poland (Nieć ed. 2013) and Portugese proposal "Towards a criteria densification to support a "safeguarding decision" on the future access to Mineral Deposits of Public Importance (MDoPI)” (Towards... 2016).

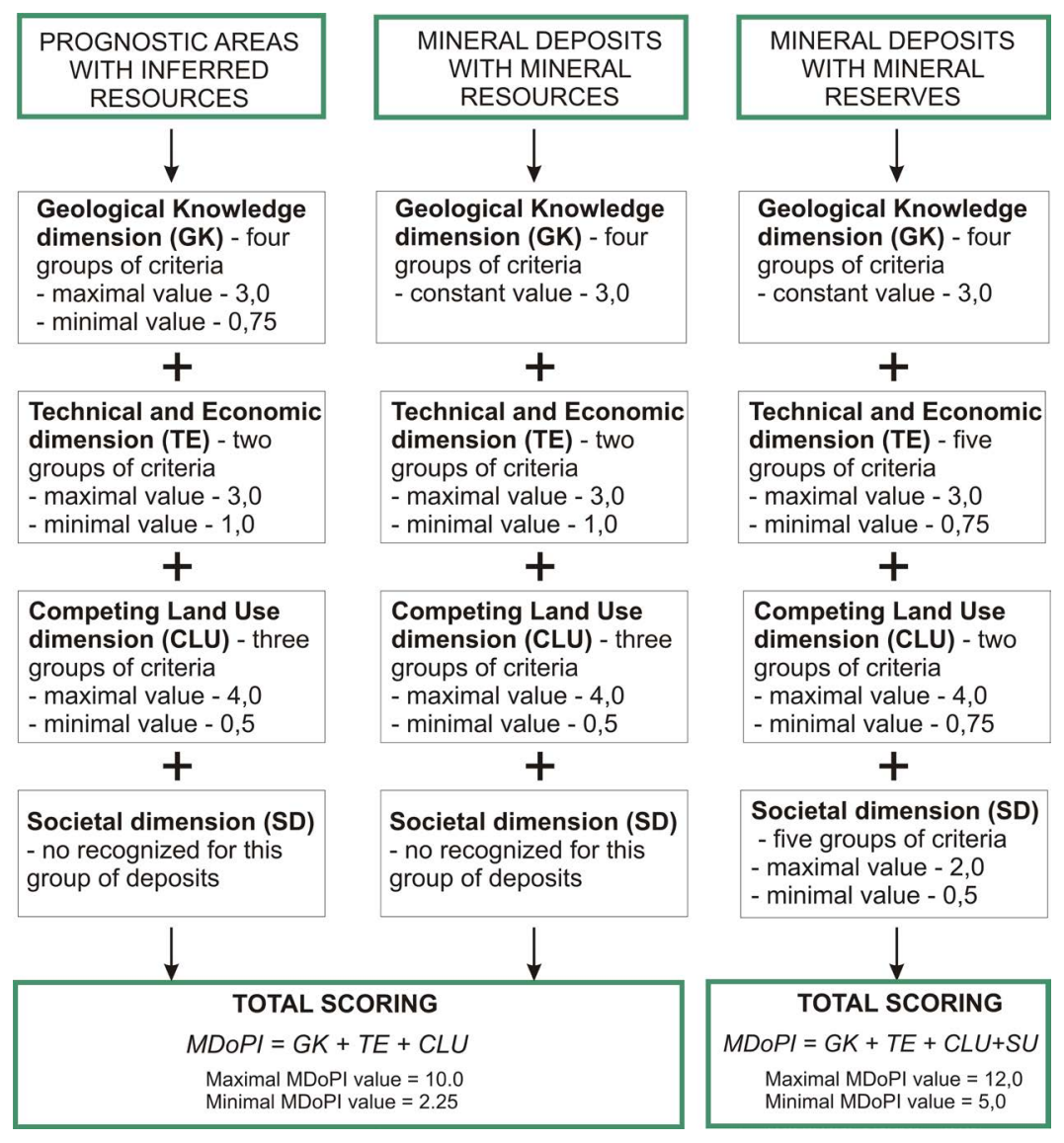

Fig. 4. General algorithm of MDoPI assignment for three levels of Geological Knowledge

Rys. 4. Ogólny algorytm wyznaczania Złóż Kopalin o Znaczeniu Publicznym dla trzech poziomów wiedzy geologicznej 
One universal methodology for all levels of geological (and economic) knowledge was proposed, though it should be kept in mind that there will be some important differences in methodological approach in each of the three levels of Geological (and Economic) Knowledge, i.e.:

1. Mineral potential areas with only hypothetical resources or promising exploration results.

2. Mineral deposits with mineral resources only (inferred, indicated, measured).

3. Mineral deposits with mineral reserves (probable, proved).

As mentioned above, assessment of mineral deposit was to be made using the following dimensions (Fig. 4): Geological Knowledge dimension (GK); Technical and Economic dimension (including geological features, TE); Competing Land Use dimension (CLU), and Societal dimension (only for mineral deposits with mineral reserves, SD).

Developed mineral deposits with mineral reserves were not the subject of testing in Poland's case. Therefore, the following detailed description of qualifying conditions is provided only for Geological Knowledge dimension, Technical and Economic dimension and Competing Land Use dimension.

\subsection{Geological knowledge dimension (GK)}

First dimension of proposed methodology was recognised and proposed as a sum of four sub-dimensions $\left(\mathrm{GK}_{1}-\mathrm{GK}_{4}\right)$ :

- $\mathbf{G K}_{1}$ criterion (weight $20 \%$ ) - availability and quality of the fundamental geological information and knowledge, in known or unknown mining/quarrying districts, thus embracing multi-scale regional information on the existent expectations of mineral concentrations (anticipated by geological models), as well as the general (lithostratigraphic, structural, geochemical, geophysical) data on the hosting environments of expected resources; ground potential for speculative to hypothetical resources, complementing the identified resources (included in the national inventory);

- $\mathbf{G K}_{2}$ criterion (weight 30\%) - regional exploration information and knowledge about mining/quarrying districts, involving all kinds of geological, geochemical and/ or geophysical data obtained in various types of exploration surveys; this criterion should reflect the exploration state-of-the-art considering the existent inventory of exploration works carried out so far in a given territory over time;

- $\mathbf{G K}_{3}$ criterion (weight 20\%) - existent information and knowledge on past exploitation, being only applicable in known mining/quarrying districts; in renowned mining/quarrying districts subjected to intensive exploitation works;

- $\mathbf{G K}_{4}$ criterion (weight 30\%) - comprehensive, up-to-date information and knowledge existent for a single specific area, maximum scoring of the $\mathrm{GK}_{4}$ criterion should correspond to areas hosting well characterised mineral resources in terms of their fundamental attributes. 
82

Kot-Niewiadomska et all 2017 / Gospodarka Surowcami Mineralnymi - Mineral Resources Management 33(3), 71-94

Table 2. Mineral Quality and Quantity (MQQ) sub-dimension for each tested group of deposits

Tabela 2. Podwymiar Jakości i Ilości Kopaliny dla każdej z testowanych grup złóż

\begin{tabular}{|c|c|c|c|}
\hline \multicolumn{4}{|c|}{ Crushed stone } \\
\hline \multirow[b]{2}{*}{ Quantity } & \multicolumn{3}{|c|}{ Quality } \\
\hline & $\begin{array}{l}>50 \% \text { of rock suitable for first class } \\
\text { aggregates }\end{array}$ & $\begin{array}{c}\text { Rock suitable mostly for medium } \\
\text { class aggregates }\end{array}$ & Other \\
\hline$>20$ million $\mathrm{t}$ & 1.0 & 1.0 & 0.5 \\
\hline 5-20 million $\mathrm{t}$ & 1.0 & 0.5 & 0.5 \\
\hline$<5$ million $\mathrm{t}$ & 0.5 & 0.5 & 0.5 \\
\hline \multicolumn{4}{|c|}{ Dimension stone } \\
\hline \multirow[b]{2}{*}{ Quantity } & \multicolumn{3}{|c|}{ Quality } \\
\hline & $\begin{array}{l}\text { The possibility of obtaining medium, } \\
\text { large and very large blocks } \\
\left(>1.0 \mathrm{~m}^{3}\right) \text { with polishing or } \\
\text { decorative properties }\end{array}$ & $\begin{array}{c}\text { The possibility of obtaining medium } \\
\text { and small blocks, } \\
\text { lack of polishing properties }\end{array}$ & $\begin{array}{l}\text { The possibility of } \\
\text { obtaining small } \\
\text { blocks }\left(<0.5 \mathrm{~m}^{3}\right)\end{array}$ \\
\hline$>10$ million $\mathrm{t}$ & 1.5 & 1.0 & 1.0 \\
\hline $10-2$ million $\mathrm{t}$ & 1.5 & 1.0 & 1.0 \\
\hline$<2$ million $\mathrm{t}$ & 1.0 & 1.0 & 1.0 \\
\hline \multicolumn{4}{|c|}{ Feldspar raw materials } \\
\hline \multirow[b]{2}{*}{ Quantity } & \multicolumn{3}{|c|}{ Quality } \\
\hline & $\begin{array}{l}\mathrm{Na}_{2} \mathrm{O}+\mathrm{K}_{2} \mathrm{O}>8.0 \% \\
\mathrm{Fe}_{2} \mathrm{O}_{3}+\mathrm{TiO}_{2} \leq 0.5 \%\end{array}$ & $\begin{array}{c}\mathrm{Na}_{2} \mathrm{O}+\mathrm{K}_{2} \mathrm{O} \geq 6.0-8.0 \% \\
\mathrm{Fe}_{2} \mathrm{O}_{3}+\mathrm{TiO}_{2} 0.5-1.0 \%\end{array}$ & Other \\
\hline$>5$ million $\mathrm{t}$ & 1.5 & 1.0 & \multirow{2}{*}{$\begin{array}{l}\text { Valorized as a } \\
\text { crushed stone }\end{array}$} \\
\hline $1-5$ million $\mathrm{t}$ & 1.0 & 1.0 & \\
\hline \multicolumn{4}{|c|}{ Kaolin } \\
\hline \multirow{2}{*}{ Quantity } & \multicolumn{3}{|c|}{ Quality } \\
\hline & \multicolumn{3}{|c|}{$<1.2 \% \mathrm{Fe}_{2} \mathrm{O}_{3}$, whiteness after firing at $1350^{\circ} \mathrm{C}>75 \%$} \\
\hline$>5$ million $\mathrm{t}$ & \multicolumn{3}{|c|}{1.5} \\
\hline $1-5$ million $\mathrm{t}$ & \multicolumn{3}{|c|}{1.5} \\
\hline$<1$ million $\mathrm{t}$ & \multicolumn{3}{|c|}{1.0} \\
\hline \multicolumn{4}{|c|}{ Glass sand } \\
\hline \multirow{2}{*}{ Quantity } & \multicolumn{3}{|c|}{ Quality } \\
\hline & \multicolumn{3}{|c|}{$>95 \% \mathrm{SiO}_{2},<0.1 \% \mathrm{Fe}_{2} \mathrm{O}_{3}$} \\
\hline$>10$ million $\mathrm{t}$ & \multicolumn{3}{|c|}{1.5} \\
\hline $10-1$ million $\mathrm{t}$ & \multicolumn{3}{|c|}{1.0} \\
\hline$<1$ million $\mathrm{t}$ & \multicolumn{3}{|c|}{0.5} \\
\hline
\end{tabular}


In each sub-dimension four complementary criteria are proposed, each one scored 0.25 , $0.50,0.75$ or 1.00 (Galos et al. 2016).

\subsection{Technical and economic dimension (TE)}

The detailed parameters of this dimension (for rock minerals) were created on the basis of the proposed mineral deposits valorisation methodology in the years 2011-2013 (Nieć ed. 2013). In respect to prognostic areas with inferred resources and mineral deposits with mineral resources, the value of this dimension was proposed as a sum of two sub-dimensions:

- Mineral Quality and Quantity (MQQ) - set of two parameters (mineral quality and quantity) would result in obtaining one of three possible values: $0.5,1.0$, or 1.5 (Table 2),

- Mining Attractiveness (MA) - set of a few parameters (e.g. for open-pits: overburden thickness, stripping ratio, water flooding, complexity of geological setting, maybe also some transportation issues) would result in obtaining one of three possible values: $0.5,1.0$, or 1.5 (Table 3 ).

Table 3. Mining Attractiveness (MA) sub-dimension for each tested group of deposits

Tabela 3. Podwymiar Atrakcyjności Górniczej dla każdej z testowanych grup złóż

\begin{tabular}{|c|c|c|c|}
\hline \multirow{2}{*}{ Stripping ratio } & \multicolumn{3}{|c|}{ Overburden thickness } \\
\hline & $<2 \mathrm{~m}$ & $2-8 \mathrm{~m}$ & $>8 \mathrm{~m}$ \\
\hline$<0.5$ & 1 & 2 & 3 \\
\hline $0.5-1.0$ & 2 & 2 & 3 \\
\hline$>1.0$ & 3 & 3 & 3 \\
\hline \multirow[b]{2}{*}{ Geological setting } & \multicolumn{3}{|c|}{ Water ingress } \\
\hline & Dry pit & $\begin{array}{l}\text { Deep pit with surface } \\
\text { water ingress only }\end{array}$ & $\begin{array}{c}\text { Deep pit with } \\
\text { groundwater ingress }\end{array}$ \\
\hline Simple (class I) & 1 & 2 & 3 \\
\hline Complex (class II) & 2 & 2 & 3 \\
\hline Very complex (class III) & 3 & 3 & 3 \\
\hline \multirow{2}{*}{$\begin{array}{l}\text { Transport conditions - } \\
\text { distance to major road }\end{array}$} & \multicolumn{3}{|c|}{ Distance to end-user } \\
\hline & $\begin{array}{l}\text { close to deposit } \\
\text { (i.e. }<50 \mathrm{~km})\end{array}$ & $\begin{array}{l}\text { far from deposit } \\
\text { (i.e. } 50-100 \mathrm{~km} \text { ) }\end{array}$ & $\begin{array}{c}\text { very far } \\
\text { (i.e. }>100 \mathrm{~km} \text { ) }\end{array}$ \\
\hline Favourable $<10 \mathrm{~km}$ & 1 & 2 & 3 \\
\hline Limited $>10 \mathrm{~km}$ & 2 & 2 & 3 \\
\hline Lack of local roads & 3 & 3 & 3 \\
\hline
\end{tabular}


The Mining Attractiveness (MA) sub-dimension value was established in two stages. In the first stage there were evaluated the following conditions: overburden thickness, geological setting and dewatering needs and the location of a deposit in respect to access routes and to consumers, according to the matrices given (Table 3). The third stage involved summing of Mining Attractiveness (MA) points and MA scoring. The total sum of points from three previous matrices was: 3-4 (MA score: 1.5), 5-6 (MA score: 1.0) or 7-9 (MA score: 0.5)

\subsection{Competing land use dimension (CLU)}

This dimension, at these levels of Geological Knowledge (prognostic areas with inferred resources, mineral deposits with mineral resources), was recognized and proposed as a sum of three sub-dimensions values:

- Nature Protection and Underground Water Protection (NUWP) sub-dimension - set of two parameters results in obtaining one of four possible values: $0.0,0.5,1.0$, or 1.5 (Table 4);

Table 4. Nature Protection and Underground Water Protection (NUWP) sub-dimension

Tabela 4. Podwymiar Ochrony Przyrody i Ochrony Wód Podziemnych

\begin{tabular}{|l|c|c|c|c|}
\hline & $\begin{array}{c}\text { No nature } \\
\text { or landscape } \\
\text { protection }\end{array}$ & $\begin{array}{c}\text { Areas of landscape } \\
\text { protection or bordering } \\
\text { NATURA 2000 areas }\end{array}$ & $\begin{array}{c}\text { Landscape Parks } \\
\text { areas and/or } \\
\text { NATURA 2000 areas }\end{array}$ & $\begin{array}{c}\text { National } \\
\text { Parks, Nature } \\
\text { Reserves }\end{array}$ \\
\hline $\begin{array}{l}\text { No underground water } \\
\text { protection }\end{array}$ & 1.5 & 1.0 & 0.5 & 0.0 \\
\hline Utility aquifer & 1.0 & 1.0 & 0.5 & 0.0 \\
\hline $\begin{array}{l}\text { Main Underground } \\
\text { Water Reservoir }\end{array}$ & 0.5 & 0.5 & 0.5 & 0.0 \\
\hline
\end{tabular}

- Forest Protection and Soil Protection (FSP) sub-dimension - set of two parameters results in obtaining one of four possible values: $0.0,0.5,1.0$, or 1.5 (Table 5);

- Housing, Infrastructure and Heritage (HIH) sub-dimension - taking into account existing or planned housing development of a deposit area, transport infrastructure, transmission networks, as well as the presence of World Heritage areas and objects of cultural heritage, it results in obtaining five possible values:

- area is built-up or occupied by heritage objects up to $10 \%$ - HIH value 1.0 ;

- area is built-up or occupied by heritage objects from 11 to $30 \%-\mathrm{HIH}$ value 0.75 ;

- area is built-up or occupied by heritage objects from 31 to $60 \%$ - HIH value 0.50 ;

- area is built-up or occupied by heritage objects from 61 to $90 \%$ - HIH value 0.25 ;

- area is built-up or occupied by heritage objects in over $90 \%-$ HIH value 0.0 . 
Table 5. Forest Protection and Soil Protection (FSP) sub-dimension

Tabela 5. Podwymiar Ochrony Lasów i Ochrony Gleb

\begin{tabular}{|l|c|c|c|}
\hline & $\begin{array}{c}\text { Low quality soils } \\
\text { only } \\
\text { (class IV-VI) }\end{array}$ & $\begin{array}{c}\text { Up to 30\% of high } \\
\text { quality soils } \\
\text { (class I-III) }\end{array}$ & $\begin{array}{c}\text { Over 30\% of high } \\
\text { quality soils } \\
\text { (class I-III) }\end{array}$ \\
\hline Lack of forest & 1.5 & 1.0 & 0.5 \\
\hline Up to $30 \%$ of deposit area covered by forest & 1.0 & 1.0 & 0.5 \\
\hline $30-90 \%$ of deposit area covered by forest & 0.5 & 0.5 & 0.5 \\
\hline Over $90 \%$ of deposit area covered by forest & 0.0 & - & - \\
\hline
\end{tabular}

\section{Pilot testing results}

The total score of MDoPI for tested deposits in the Dolnośląskie Province varied from 6.0 to 9.0 points (Table 6 )

Table 6. The results of testing process for minerals deposits with indicated and measured resources, with proposed initial MDoPI classification

Tabela 6. Wyniki procesu testowania udokumentowanych złóż, z wstępną propozycją klasyfikacji Złóż Kopalin o Znaczeniu Publicznym

\begin{tabular}{|c|c|c|c|c|c|c|}
\hline & Name of deposit & GK & $\mathrm{TE}$ & CLU & Total scoring & MDoPI classification \\
\hline \multicolumn{7}{|c|}{ CRUSHED AND DIMENSION STONE } \\
\hline \multicolumn{7}{|c|}{ BASALT } \\
\hline 1 & Gronów & 3.0 & 1.5 & 3.0 & 7.5 & MDoPI-RL \\
\hline 2 & Liściasta Góra & 3.0 & 2.0 & 2.5 & 7.5 & MDoPI-RL \\
\hline 3 & Mszana-Obłoga & 3.0 & 1.5 & 1.0 & 5.5 & Non-MDoPI \\
\hline 4 & Paszowice & 3.0 & 1.5 & 1.5 & 6.0 & Non-MDoPI \\
\hline 5 & Sichów & 3.0 & 1.5 & 2.5 & 7.0 & Non-MDoPI \\
\hline 6 & Targowica-Wschód & 3.0 & 1.5 & 3.0 & 7.5 & MDoPI-RL \\
\hline \multicolumn{7}{|c|}{ GRANITE, GRANODIORITE, SYENITE } \\
\hline 7 & Ząbkowice Śląskie & 3.0 & 1.5 & 4.0 & 8.5 & MDoPI-CL \\
\hline \multicolumn{7}{|c|}{ GRANITE, GRANODIORITE, SYENITE } \\
\hline 8 & Brodziszów I & 3.0 & 2.0 & 2.5 & 7.5 & MDoPI-RL \\
\hline 9 & Chwalisław & 3.0 & 2.0 & 1.5 & 6.5 & Non-MDoPI \\
\hline
\end{tabular}


Table 6. cont.

Tabela 6. cd.

\begin{tabular}{|c|c|c|c|c|c|c|}
\hline \multicolumn{2}{|r|}{ Name of deposit } & GK & $\mathrm{TE}$ & CLU & Total scoring & MDoPI classification \\
\hline 10 & Gniewków I & 3.0 & 1.5 & 4.0 & 8.5 & MDoPI-CL \\
\hline 11 & Karpniki-Strużnica & 3.0 & 1.5 & 2.0 & 6.5 & Non-MDoPI \\
\hline 12 & Kostrza Jerzy-Wschód & 3.0 & 2.0 & 3.0 & 8.0 & MDoPI-RL \\
\hline 13 & Łażany & 3.0 & 1.5 & 4.0 & 8.5 & MDoPI-CL \\
\hline 14 & Michałowice & 3.0 & 2.0 & 2.0 & 7.0 & Non-MDoPI \\
\hline 15 & Morawa-Wschód & 3.0 & 2.0 & 4.0 & 9.0 & MDoPI-CL \\
\hline 16 & Mrowiny & 3.0 & 2.0 & 3.0 & 8.0 & MDoPI-RL \\
\hline 17 & Mrowiny I & 3.0 & 2.0 & 3.0 & 8.0 & MDoPI-RL \\
\hline 18 & Mrowiny II & 3.0 & 2.0 & 2.5 & 7.5 & MDoPI-RL \\
\hline 19 & Mrowiny III & 3.0 & 2.0 & 3.0 & 8.0 & MDoPI-RL \\
\hline 20 & Piekielnik & 3.0 & 1.5 & 2.5 & 7.0 & Non-MDoPI \\
\hline 21 & Rogoźnica-Południe & 3.0 & 2.0 & 3.25 & 8.25 & MDoPI-CL \\
\hline 22 & Rogoźnica & 3.0 & 2.0 & 3.0 & 8.0 & MDoPI-RL \\
\hline 23 & Rogówka & 3.0 & 2.0 & 2.5 & 7.5 & MDoPI-RL \\
\hline 24 & Strzegów I & 3.0 & 2.0 & 3.0 & 8.0 & MDoPI-RL \\
\hline 25 & Strzegom II & 3.0 & 2.5 & 3.0 & 8.5 & MDoPI-CL \\
\hline 26 & Wiciarka & 3.0 & 2.5 & 1.5 & 7.0 & Non-MDoPI \\
\hline 27 & Zamczysko & 3.0 & 1.5 & 2.5 & 7.0 & Non-MDoPI \\
\hline 28 & Zimnik II & 3.0 & 1.5 & 3.0 & 7.5 & MDoPI-RL \\
\hline 29 & Żółkiewka II & 3.0 & 2.0 & 4.0 & 9.0 & MDoPI-CL \\
\hline \multicolumn{7}{|c|}{ PORPHYRY, MELAPHIRE } \\
\hline 30 & Chełmczyk & 3.0 & 1.5 & 2.5 & 7.0 & Non-MDoPI \\
\hline 31 & Chełmczyk I & 3.0 & 2.0 & 2.5 & 7.5 & MDoPI-RL \\
\hline 32 & Czarny Bór & 3.0 & 1.5 & 4.0 & 8.5 & MDoPI-CL \\
\hline 33 & Lubawka I & 3.0 & 1.5 & 1.5 & 6.0 & Non-MDoPI \\
\hline 34 & Lubawka II & 3.0 & 1.5 & 2.0 & 6.5 & Non-MDoPI \\
\hline 35 & Lubrza & 3.0 & 2.0 & 2.0 & 7.0 & Non-MDoPI \\
\hline 36 & Rybnica I & 3.0 & 2.0 & 2.0 & 7.0 & Non-MDoPI \\
\hline 37 & Rybnica & 3.0 & 2.0 & 2.0 & 7.0 & Non-MDoPI \\
\hline \multicolumn{7}{|c|}{ AMHPIBOLITE, SERPENTINITE } \\
\hline 38 & Jurczyce & 3.0 & 1.5 & 3.0 & 7.5 & MDoPI-RL \\
\hline 39 & Koziniec & 3.0 & 1.5 & 3.0 & 7.5 & MDoPI-RL \\
\hline 40 & Tomice & 3.0 & 2.0 & 4.0 & 9.0 & MDoPI-CL \\
\hline 41 & Wieściszowice & 3.0 & 2.0 & 2.5 & 7.5 & MDoPI-RL \\
\hline
\end{tabular}


Table 6. cont.

Tabela 6. cd.

\begin{tabular}{|c|c|c|c|c|c|c|}
\hline & Name of deposit & GK & TE & CLU & Total scoring & MDoPI classification \\
\hline \multicolumn{7}{|c|}{ GNEISS, MIGMATITE } \\
\hline 42 & Kluczowa & 3.0 & 2.0 & 4.0 & 9.0 & MDoPI-CL \\
\hline 43 & Padole & 3.0 & 1.5 & 1.5 & 6.0 & Non-MDoPI \\
\hline 44 & Stankowice & 3.0 & 2.0 & 3.0 & 8.0 & MDoPI-RL \\
\hline \multicolumn{7}{|c|}{ MARBLE, DOLOMITE MARBLE } \\
\hline 45 & Kletno IV & 3.0 & 1.5 & 1.5 & 6.0 & Non-MDoPI \\
\hline 46 & Nowy Waliszów & 3.0 & 1.5 & 3.0 & 7.5 & MDoPI-RL \\
\hline 47 & Podgórki & 3.0 & 2.0 & 1.0 & 6.0 & Non-MDoPI \\
\hline 48 & Różanka & 3.0 & 1.5 & 1.5 & 6.0 & Non-MDoPI \\
\hline 49 & Słupiec & 3.0 & 2.0 & 1.5 & 6.5 & Non-MDoPI \\
\hline 50 & Czarnów & 3.0 & 2.0 & 3.0 & 8.0 & MDoPI-RL \\
\hline \multicolumn{7}{|c|}{ FELDSPAR RAW MATERIALS } \\
\hline 51 & Góra Sośnia (Dziwiszów) & 3.0 & 2.0 & 3.0 & 8.0 & MDoPI-CL \\
\hline 52 & Kamienica Mała & 3.0 & 2.0 & 3.5 & 8.5 & MDoPI-CL \\
\hline 53 & Kopaniec & 3.0 & 2.0 & 2.5 & 7.5 & MDoPI-RL \\
\hline 54 & Maciejowa & 3.0 & 1.5 & 3.5 & 8.0 & MDoPI-CL \\
\hline 55 & Maciejowa II & 3.0 & 1.5 & 3.5 & 8.0 & MDoPI-CL \\
\hline 56 & Proszowa-Kwieciszowice & 3.0 & 2.5 & 2.5 & 8.0 & MDoPI-CL \\
\hline \multicolumn{7}{|c|}{ KAOLIN } \\
\hline 57 & Antoni (Kalno) & 3.0 & 2.0 & 2.25 & 7.25 & MDoPI-RL \\
\hline 58 & Gola & 3.0 & 2.0 & 2.5 & 7.5 & MDoPI-RL \\
\hline 59 & Julia (Dzierżków-Roztoka) & 3.0 & 2.0 & 2.5 & 7.5 & MDoPI-RL \\
\hline 60 & $\begin{array}{l}\text { Kazimierz (Godzieszówek- } \\
\text { Tomkowice) }\end{array}$ & 3.0 & 2.0 & 2.0 & 7.0 & MDoPI-RL \\
\hline 61 & $\begin{array}{l}\text { Michał (Dzierżków- } \\
\text { Roztoka) }\end{array}$ & 3.0 & 2.0 & 3.0 & 8.0 & MDoPI-CL \\
\hline 62 & Monika & 3.0 & 2.0 & 2.5 & 7.5 & MDoPI-RL \\
\hline 63 & Stefan (Bolesławiec) & 3.0 & 2.0 & 2.0 & 7.0 & MDoPI-RL \\
\hline 64 & Śmiałowice & 3.0 & 2.0 & 2.25 & 7.25 & MDoPI-RL \\
\hline 65 & Zofia (Czerwona Woda) & 3.0 & 2.0 & 2.75 & 7.75 & MDoPI-CL \\
\hline 66 & Żarów & 3.0 & 2.0 & 1.5 & 6.5 & MDoPI-RL \\
\hline \multicolumn{7}{|c|}{ GLASS SAND } \\
\hline 67 & Ołobola & 3,0 & 2,0 & 1,25 & 6,25 & MDoPI-RL \\
\hline 68 & Krzeszówek I & 3,0 & 2,0 & 2,0 & 7,0 & MDoPI-RL \\
\hline 69 & Osiecznica I & 3,0 & 2,0 & 1,5 & 6,5 & MDoPI-RL \\
\hline 70 & Osiecznica-Stanisława & 3,0 & 2,0 & 1,5 & 6,5 & MDoPI-RL \\
\hline 71 & Parowa & 3,0 & 2,0 & 1,5 & 6,5 & MDoPI-RL \\
\hline 72 & Parowa 1 - Pole II, IV & 3,0 & 2,5 & 1,5 & 7,0 & MDoPI-RL \\
\hline 73 & Władysława & 3,0 & 2,0 & 1,5 & 6,5 & MDoPI-RL \\
\hline
\end{tabular}


The record score (9.0) obtained only 4 deposits of crushed and dimension stone. For 50 tested deposits of this minerals group, 7 deposits have total MDoPI value up to 6.0, 13 deposits - over 6.0 up to 7.0, 20 deposits - over 7.0 up to 8.0, 10 deposits - over 8.0. In this case it is proposed to put the threshold between MDoPI-CL and MDoPI-RL at 8.0, while between MDoPI-RL and non-MDoPI at 7.0. According to such assumption, 10 of 50 tested deposits of crushed and dimension stone would be (initially) recognised as MDoPI-CL, while another 20 deposits as MDoPI-RL. The remaining 20 deposits would be recognised as non-MDoPI (Table 6). For example, 5 granite deposits in the Świdnica District have been qualified as MDoPICL, while the next 5 as MDoPI-RL (Fig. 5).

For 6 tested deposits of feldspar raw materials, 1 deposit scored 7.5 points, 4 deposits 8.0, and 1 deposit -8.5 . In this case it is proposed to place the threshold between MDoPI-CL and MDoPI-RL at 7.5, and all deposits having total MDoPI value max. 7.5 would be recognised as MDoPI-RL. According to such assumption, 5 of 6 tested deposits of feldspar raw materials would be (initially) recognised as MDoPI-CL (Table 6), while 1 deposit - as MDoPI-RL (Kopaniec deposit in Jelenia Góra District, Fig. 6).
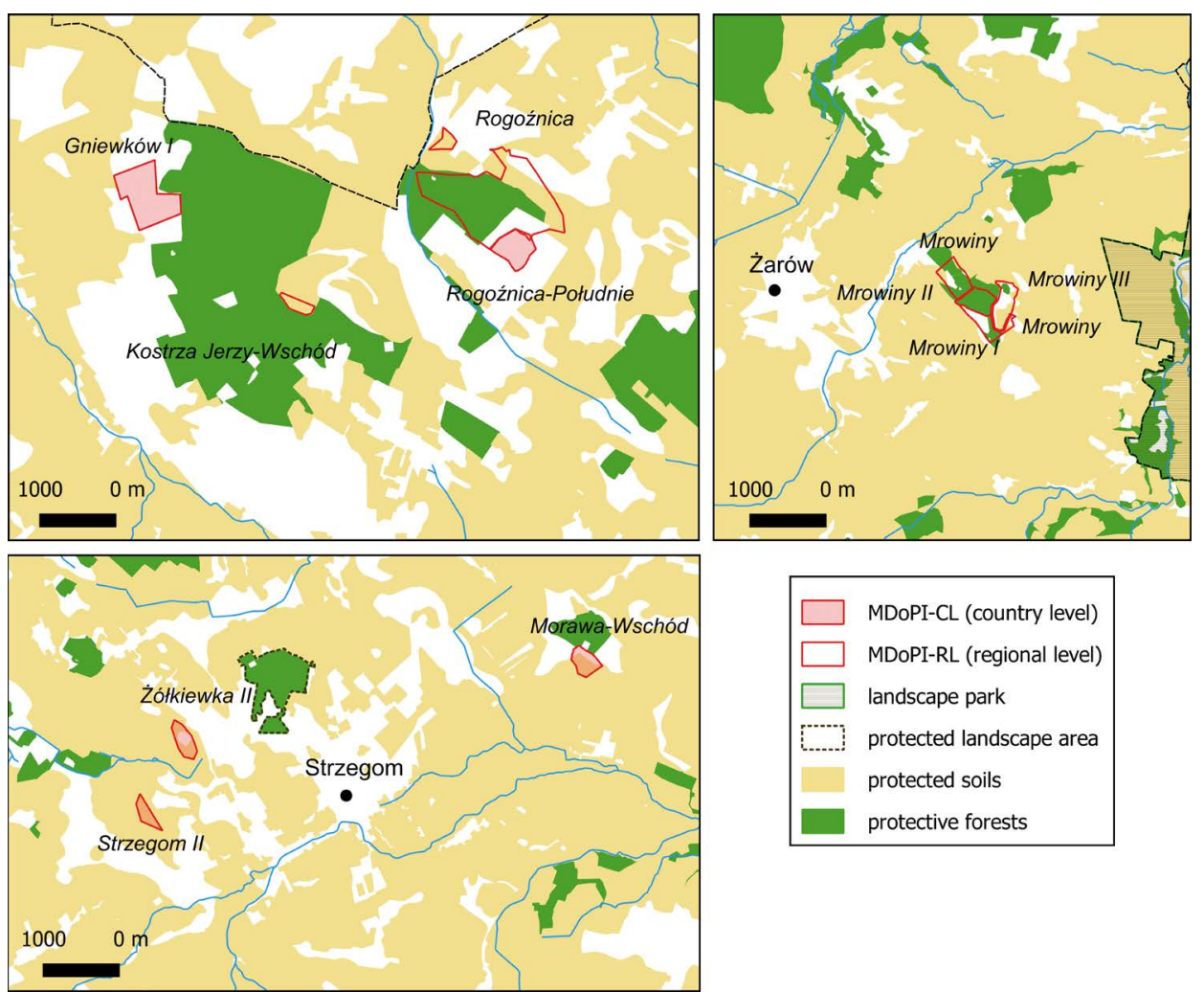

Fig. 5. The results of testing process for granite deposits in the Świdnica District

Rys. 5. Wyniki procesu testowania dla złóż granitu w powiecie świdnickim 

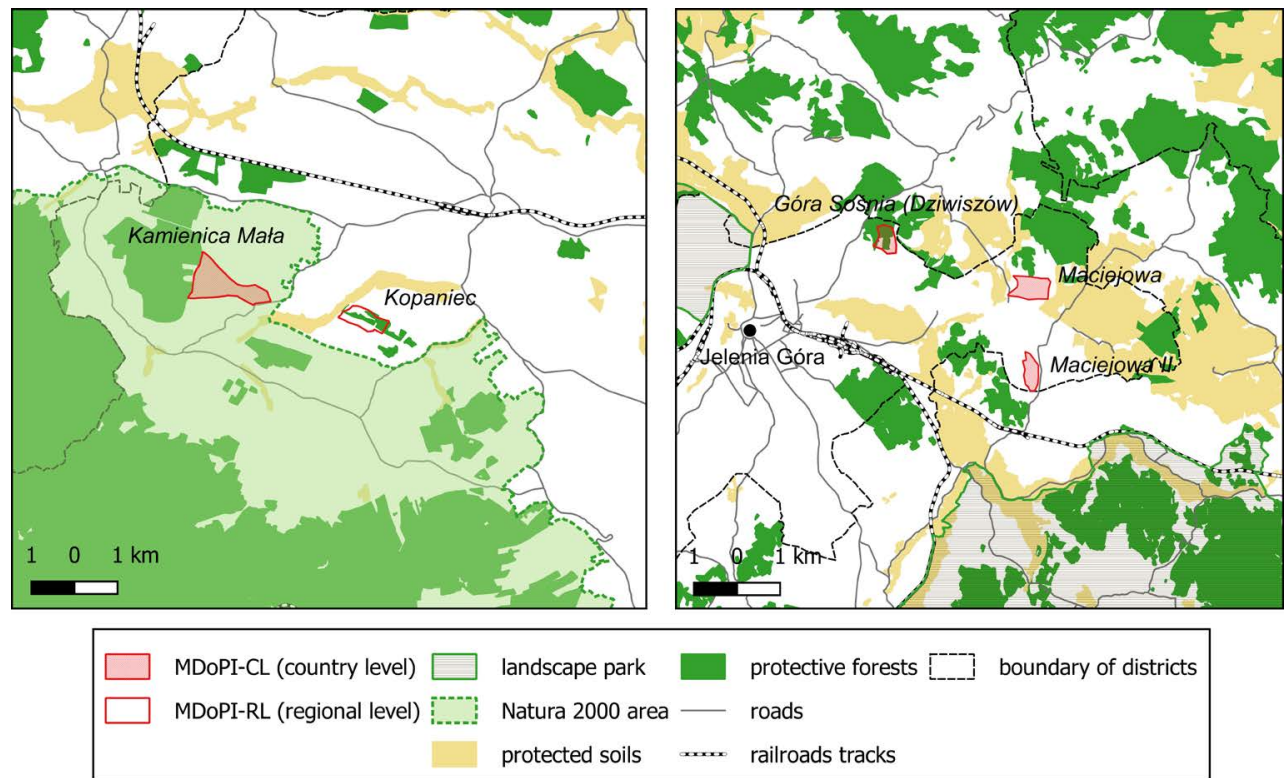

Fig. 6. The results of testing process for feldspar raw materials deposits in the Jelenia Góra District

Rys. 6. Wyniki procesu testowania dla złóż kopalin skaleniowych w powiecie jeleniogórskim

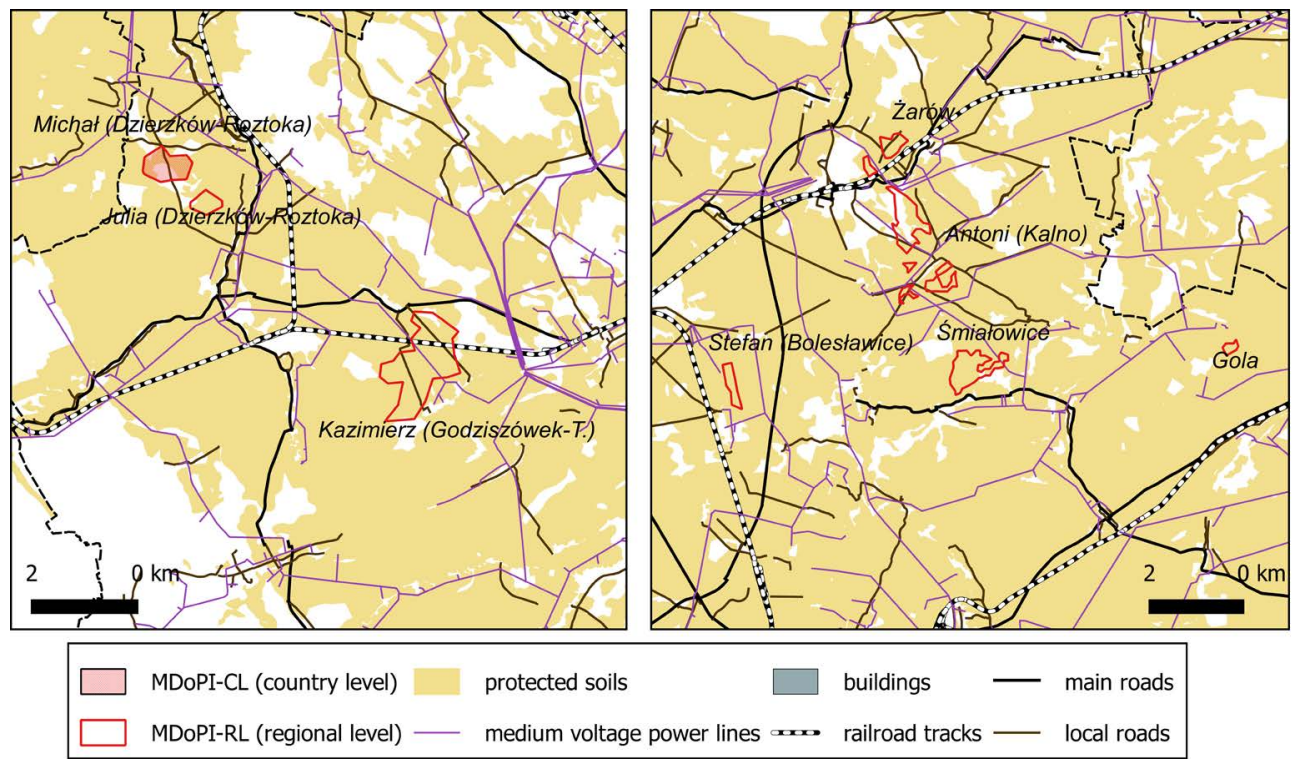

Fig. 7. The results of testing process for kaolin deposits in the Świdnica District

Rys. 7. Wyniki procesu testowania dla złóż kaolinu w powiecie świdnickim 
Among 10 tested deposits of kaolin, 3 deposits have total MDoPI value up to 7.0, 5 deposits - value 7.5, and 2 deposits - value 8.0. In this case it is proposed to put the threshold between MDoPI-CL and MDoPI-RL at 7.5, and all deposits having total MDoPI value max. 7.5 would be recognised as MDoPI-RL. According to such assumption, 2 of 10 tested deposits of kaolin would be (initially) recognised as MDoPI-CL, while the remaining 8 deposits MDoPI-RL (all are located in Świdnica District, Fig. 7).

Among 7 tested deposits of sand for glass production, 5 deposits have total MDoPI value 6.5 , while 2 deposits -7.0 (tab. 8). In this case it is proposed to place the threshold between MDoPI-CL and MDoPI-RL at 7.5, while all deposits with total MDoPI value max. 7.5 would be recognized as MDoPI-RL. According to such assumption, all tested deposits of sand for glass production would be (initially) recognized as MDoPI-RL.

\section{Conclusions and recommendations}

MINATURA2020 Project is aimed to develop and propose concept and methodology of assignment and subsequent recommendations to ensure their safeguarding as Mineral Deposits of Public Importance (MDoPI), in order to ensure their optimal use for future needs of the European society for minerals. Selection of MDoPIs must be preceded by multi-criteria valorisation of a whole set of known deposits, taking into account geological, mining, environmental, land use, economic, and social criteria.

Methodology of MDoPI assignment proposed in MINATURA2020 project was tested in a few EU regions (the whole area of Slovenia, selected regions of Poland, Hungary, Italy, Portugal, Sweden, offshore area between the UK and Ireland). One of the tested areas was the Dolnośląskie Province in Poland, with 4 selected groups of minerals, undeveloped deposits of which have been tested. Initially there were selected 144 deposits of magmatic and metamorphic crushed and dimension stone, 6 deposits of feldspar raw materials, 11 deposits of kaolin, and 7 deposits of glass sand. From among them, for further testing there were qualified deposits having highest or medium class of geological features according to methodology of valorisation of unexploited rock mineral deposits (Nieć ed. 2013). Finally, the proposed methodology of MDoPI designation has been tested for 73 mineral deposits with indicated and/or measured resources, including: 50 deposits of magmatic and metamorphic crushed and dimension stone, 6 deposits of feldspar raw materials, 10 deposits of kaolin and 7 deposits of glass sand.

For deposits of crushed and dimension stone, a threshold between MDoPI-CL and MDoPI-RL was proposed at 8.0 (of maximum 10), while between MDoPI-RL and nonMDoPI - at 7.0. For deposits of feldspar raw materials, kaolin and glass sand a threshold between MDoPI-CL and MDoPI-RL was proposed at 7.5. So, finally - according to assumed MDoPI methodology and thresholds, 10 of 50 tested deposits of crushed and dimension stone have been recognized as MDoPI-CL, while another 20 deposits as MDoPI-RL, 5 of 6 tested deposits of feldspar raw materials have been recognised as MDoPI-CL, while 1 de- 
posit as MDoPI-RL, 2 of 10 tested deposits of kaolins have been recognised as MDoPI-CL, while the remaining 8 deposits MDoPI-RL, and all 7 tested deposits of glass sand have been recognised as MDoPI-RL. In total, from among 73 tested deposits, 17 deposits were proposed as MDoPI-CL, whereas 36 deposits as MDOPI-RL.

On the basis of performed testing, it can be concluded that the main strength of proposed methodology is the possibility to use multi-criterion methodology containing a number of geological-mining, environmental and spatial factors, giving possibility of categorisation of deposits according to their economic importance (EU, country and regional level) for their further safeguarding. In Polish terms, this methodology can be used in a very detailed way, having high level of geological recognition of Poland and - usually - of individual deposits, as well as easy access to geological, mining, environmental and land use data. The further necessary step is an introduction of legal system of MDoPI safeguarding as a part of prepared Polish Mineral Policy.

Some important weaknesses of proposed methodology of MDoPI assignment should also be emphasised, e.g. a lack of social criterion for analysed group of undeveloped deposits, perhaps overestimated environmental criterion, and subjective values of thresholds between MDoPI and Non-MDoPI and - consequently - between MDoPI-EU, MDoPI-CL, and MDoPI-RL. Moreover, this methodology (as well as any other one) cannot be applied in practice, when Polish legal system is - in fact - still unprepared for actual mineral deposits safeguarding. However, if legal system of mineral deposits safeguarding is efficiently introduced in Poland, this methodology will be a useful tool for selecting the most valuable mineral deposits that should be protected.

This paper was prepared on the basis of results of MINATURA2020 Project, which received funding from the European Union's Horizon 2020 research and innovation programme under grant agreement $n^{\circ} 642139$

\section{REFERENCES}

Central Geological Database 2017 - Centralna Baza Danych Geologicznych PIG-PIB. [Online] Available at: www.baza.pgi.gov.pl [Accessed: 15.05.2017].

Central Statistical Office 2016 - Bank Danych Lokalnych Głównego Urzędu Statystycznego. [Online] Available at: www.bdl.stat.gov.pl [Accessed: 30.04.2016].

Der Österreichische Rohstoffplan (Austrian Mineral Resources Plan) (2012). Wien: Geologische Bundesanstalt, $263 \mathrm{p}$.

Development Strategy of the Dolnośląskie Province 2020 (Strategia Rozwoju Województwa Dolnośląskiego 2020). Dolnośląski Urząd Marszałkowski, Wrocław, 2013.

EC Enterprise and Industry 2010. Improving Framework conditions for extracting minerals for the EU. Brussels: European Commission, Enterprise and Industry, 58 p.

EC Enterprise and Industry 2013. Strategic Implementation Plan for the European Innovation Partnership on Raw Materials. Part I. Brussels: European Commission, Enterprise and Industry, 23 p.

EC Enterprise and Industry 2014. Recommendations on the framework conditions for the extraction on non-energy 
raw materials in the European Union. Report of the Ad Hoc Working Group on Exchange of best practices on minerals policy and legal framework, information framework, land-use planning and permitting. Brussels: European Commission, Enterprise and Industry, $35 \mathrm{p}$.

Galos et al. 2012 - Galos, K., Nieć, M., Radwanek-Bąk, B., Smakowski, T. and Szamałek, K. 2012. Bezpieczeństwo surowcowe Polski w Unii Europejskiej i na świecie. Biuletyn PIG 452, pp. 43-52.

Galos et al. 2016 - Galos, K., Kot-Niewiadomska, A. and Nieć, M. 2016. MINATURA2020 Project. MINATURA Deliverable 2.2. Set of qualifying conditions for a harmonised mapping framework (HMF) for each type of mineral (manuscript).

Galos, K. 2013. Strategie surowcowe wybranych krajów Unii Europejskiej. Zeszyty Naukowe IGSMiE PAN, 85, pp. 29-46.

Galos K. and Nieć M. 2015. Europejska koncepcja złóż kopalin o znaczeniu publicznym (projekt MINATURA2020) Zeszyty Naukowe IGSMiE PAN, 91, pp. 35-43.

Galos, K. and Smakowski, T. 2008. Nowa polityka surowcowa Unii Europejskiej. Gospodarka Surowcami Mineralnymi-Mineral Resources Management 24, 4, pp. 75-90.

General Directorate for Environmental Protection - Generalna Dyrekcja Ochrony Środowiska. [Online] Available at: www.gdos.gov.pl [Accessed: 15.05.2017].

Kot-Niewiadomska, A. and Kamyk, J. 2017. Wpływ zapisów dokumentów strategicznych województwa dolnośląskiego na możliwość prowadzenia działalności wydobywczej. Górnictwo Odkrywkowe 58, 3, pp. 41-48.

Minatura2020, 2016 - MINATURA2020 - Mineral Deposits of Public Importance. Press release 12 June 2015. [Online] Available at: http://minatura2020.eu/wp-content/uploads/2015/06/MINATURA-PR-JUNE2015.pdf [Accessed: 31.08.2017].

Mineral Resources Datafile 2016 - Bilans Zasobów Złóż Kopalin w Polsce wg stanu na 31.12.2015 r. Warszawa: Wyd. PIG-PIB, $475 \mathrm{~s}$.

Nieć et al. 2014 - Nieć, M., Galos, K. and Szamałek, K. 2014. Main challenges of mineral resources policy of Poland. Resources Policy 42, pp. 93-103.

Nieć, M. red. 2013. Waloryzacja niezagospodarowanych złóż kopalin skalnych w Polsce. Wyd. IGO Poltegor Instytut, Wrocław, $201 \mathrm{pp}$

Riksintresse för värdefulla ämnen eller material (Mineral deposits of national interest) (2016). [Online] Available at: www.sgu.se/en/mineral-resources/mineral-deposits-of-national-interest [Accessed: 31.12.2016].

Spatial Development Plan of the Dolnoślaskie Province - 2020 Perspective (Plan Zagospodarowania Przestrzennego Województwa Dolnośląskiego - Perspektywa 2020). Dolnośląski Urząd Marszałkowski, Wrocław, 2014.

Tiess, G. 2011. Legal Basics of Mineral Policy in Europe: An overview of 40 countries. Wien: Springer Verlag, $394 \mathrm{pp}$.

Towards a criteria densification to support a "safeguarding decision" on the future access to Mineral Deposits of Public Importance (MDoPI). Fundacao da Faculdade de Ciencias da Universidade de Lisboa, 2016 (manuscript).

Wrighton et al. 2014 - Wrighton, C.E., Bee, E.J. and Mankelow, J.M. 2014. The development and implementation of mineral safeguarding policies at national and local levels in the United Kingdom. Resources Policy 41, pp. $160-170$ 


\section{METODYKA WYZNACZANIA ZŁÓŻ KOPALIN O ZNACZENIU PUBLICZNYM \\ ZAPROPONOWANA W PROJEKCIE MINATURA2020 \\ ORAZ REZULTATY JEJ TESTOWANIA W WOJEWÓDZTWIE DOLNOŚLĄSKIM (POLSKA)}

Słowa kluczowe

MINATURA2020, złoża kopalin o znaczeniu publicznym, ochrona złóż kopalin,

waloryzacja złóż kopalin

\section{Streszczenie}

Głównym celem projektu MINATURA2020 było opracowanie koncepcji i wielowymiarowej metodyki wyznaczania oraz - w konsekwencji - ochrony Złóż Kopalin o Znaczeniu Publicznym (ZKoZP) na poziomie UE (ZKoZP-UE), krajowym (ZKoZP-PK) i regionalnym (ZKoZP-PR), w celu zabezpieczenia ich optymalnego wykorzystania dla przyszłych potrzeb społeczeństwa. Metodyka wyznaczania ZKoZP zaproponowana w ramach projektu MINATURA2020 była testowana w kilku regionach UE, w tym w województwie dolnośląskim. W tym przypadku analizie poddano niezagospodarowane złoża czterech grup kopalin: magmowych i metamorficznych kamieni łamanych i blocznych (144 złoża), kopalin skaleniowych (6 złóż), kaolinów (11 złóż) oraz piasków szklarskich (7 złóż). Następnie wybrano spośród nich 73 złoża o najlepszych parametrach geologicznych i górniczych: 50 złóż magmowych i metamorficznych kamieni łamanych i blocznych, 6 złóż kopalin skaleniowych, 10 złóż kaolinów oraz 7 złóż piasków szklarskich. Ostatecznie, zgodnie z zaproponowaną metodyką wyznaczania ZKoZP, spośród 50 testowanych złóż kamieni łamanych i blocznych, za ZKoZP-PK uznano 10 złóż, a za ZKoZP-PR - kolejne 20 złóż. W przypadku testowanych złóż kopalin skaleniowych 5 spośród 6 zaliczono do ZKoZP-PK, a 1 do ZKoZP-PR, natomiast wśród 10 testowanych złóż kaolinów 2 zakwalifikowano do ZKoZP-PK, a 8 do ZKoZP-PR. Wszystkie 7 testowanych złóż piasków szklarskich zaliczono do ZKoZP-PR. Łącznie, spośród 73 analizowanych złóż, 17 złóż zaproponowano zaliczyć do ZKoZP-PK, a 36 - do ZKoZP-PR.

Na podstawie wykonanego pilotażowego testowania można stwierdzić, że główną zaletą zaproponowanej metodyki jest możliwość użycia analizy wielokryterialnej uwzględniającej liczne czynniki geologiczno-górnicze, środowiskowe i przestrzenne, co stwarza możliwość kategoryzacji złóż zgodnie z ich potencjalnym znaczeniem gospodarczym (na poziomie UE, kraju, regionu) dla celów ich przyszłej ochrony. Co więcej, jeśli system prawny ochrony złóż kopalin zostanie w Polsce efektywnie wprowadzony, metodyka ta może być przydatnym narzędziem do wyboru najcenniejszych złóż, które powinny podlegać ochronie. 


\title{
METHODOLOGY OF ASSIGNMENT OF MINERAL DEPOSITS \\ OF PUBLIC IMPORTANCE PROPOSED BY MINATURA2020 PROJECT AND RESULTS OF ITS PILOT TESTING IN THE DOLNOŚLĄSKIE PROVINCE (SW POLAND)
}

\author{
Keywords
}

MINATURA2020, mineral deposits of public importance, deposits' safeguarding, deposits' valorisation

Abstract

MINATURA2020 project's aim is to develop a concept and multi-dimensional methodology of assignment and - in a consequence - of safeguarding the Mineral Deposits of Public Importance (MDoPI) at European (EU), country (CL) and regional/local level (RL), in order to ensure their optimal use for future needs of the society. MDoPI assignment methodology proposed within MINATURA2020 project, was tested within a few EU regions, including Dolnośląskie Province in Poland, where undeveloped deposits were verified. Initially, deposits of 4 selected groups of minerals were tested: magmatic and metamorphic crushed and dimension stone (144 deposits), feldspar raw materials (6 deposits), kaolin (11 deposits), and glass sand (7 deposits). In the following step, the deposits of the highest or medium class of geological features were chosen, i.e. 73 mineral deposits with indicated and/or measured resources, including: 50 deposits of magmatic and metamorphic crushed and dimension stone, 6 deposits of feldspar raw materials, 10 deposits of kaolin and 7 deposits of glass sand. Finally, according to assumed MDoPI methodology, 10 of 50 tested deposits of crushed and dimension stone were qualified as MDoPI-CL, while another 20 deposits as MDoPI-RL, 5 of 6 deposits of feldspar raw materials were ranked as MDoPI-CL, while 1 deposit as MDoPI-RL, 2 of 10 kaolin deposits were categorised as MDoPI-CL, while the remaining 8 deposits MDoPI-RL, and all of 7 tested deposits of glass sand were qualified as MDoPI-RL. In total, from among 73 verified deposits, 17 deposits were proposed as MDoPI-CL, whereas 36 deposits were qualified as potential MDoPI-RL.

On the basis of performed testing, it can be concluded that the main strength of proposed methodology is the possibility to use multi-criterion methodology containing a number of geological-mining, environmental and spatial factors, giving possibility to categorization of deposits according to their economic importance (EU, country and regional level) for their further safeguarding. Moreover, if legal system of mineral deposits safeguarding is efficiently introduced in Poland, this methodology will be a useful tool for selecting the most valuable mineral deposits that should be protected. 